\title{
FAKTOR-FAKTOR YANG MEMPENGARUHI KEPATUHAN WAJIB PAJAK DENGAN KESADARAN PERPAJAKAN SEBAGAI VARIABEL MODERATING
}

\author{
Siti Dewi Yuliani \\ Universitas Islam Negeri Maulana Malik Ibrahim Malang, \\ Jl. Gajayana No. 50 Malang, 65144, Indonesia \\ e-mail : stdewiyuliani2207@gmail.com \\ Nina Dwi Setyaningsih \\ Universitas Islam Negeri Maulana Malik Ibrahim Malang \\ Jl. Gajayana No. 50 Malang, 65144, Indonesia \\ e-mail : Shirlytania@yahoo.com
}

\section{Abstract}

The development of Business, Micro, Small, Medium Enterprises (UMKM) in Indonesia is currently experiencing a very drastic increase. The development of UMKM from year to year shows a significant number. This increase makes UMKM have enormous potential for the country's income. This study aims to describe whether perceptions of fairness, taxation security, changes in tax rates affect taxpayer compliance with tax awareness as a moderating variable for UMKM players after the application of PP No. 23 of 2018. This research employed quantitative methods. Moreover, respondents in this research were UMKM entrepreneurs registered at KPP Pratama Bojonegoro. The researcher used simple random sampling as the method of sampling where the distribution of questionnaires was done randomly without considering the level in a population. Furthermore, data collection was done by using a questionnaire technique. The results of this study explain that the variable Justice Perception (X1) influences Taxpayer Compliance proven by the significant value of $43.2 \%$, Taxation Understanding (X2) controls Taxpayer Compliance as evidenced by the considerable amount of $74.5 \%$, The Changes of Rates do not affect the Taxpayer Compliance as evidenced by significant value of $28.8 \%$, and Tax Awareness (M) is not a variable that strengthens or weakens the relationship.

Keywords: Perception of Justice, Understanding of Taxation, Changes in Rates, Awareness of Taxation; Compliance of Taxpayers

\section{Abstrak}

Pertumbuhan Usaha, Mikro, Kecil, Menengah (UMKM) di Indonesia saat ini mengalami peningkatan yang sangat drastis. Perkembangan UMKM dari tahun ke tahun menunjukkan angka yang tinggi. Penelitian ini bertujuan untuk mengetahui apakah persepsi keadilan, pehamaman perpajakan, perubahan tarif pajak berpengaruh terhadap kepatuhan wajib pajak dengan kesadaran perpajakan sebagai variabel moderating pada pelaku UMKM setelah penerapan PP No 23 Tahun 2018. Penelitian ini menggunakan metode kuantitatif. Responden dalam penelitian ini adalah pengusaha UMKM yang terdaftar di KPP Pratama Bojonegoro. Metode yang digunakan dalam pengambilan sampel, peneliti menggunakan metode simple random sampling. Dimana penyebaran kuesioner dilakukan secara acak tanpa memandang tingkatan dalam sebuah populasi. Teknik pengumpulan data dengan menggunakan kuesioner/ angket. Hasil dari penelitian ini menunjukkan bahwa variabel Persepsi Keadilan (X1) berpengaruh terhadap Kepatuhan Wajib Pajak dibuktikan dengan nilai siginifakan sebesar 43,2 \%, 
Siti Dewi Yuliani dan Nina Dwi Setyaningsih: Faktor-Faktor yang Mempengaruhi Kepatuhan Wajib Pajak dengan Kesadaran Perpajakan sebagai Variabel Moderating

Pemahaman Perpajakan (X2) berpengaruh terhadap Kepatuhan Wajib Pajak dibuktikan dengan nilai siginifakan sebesar 74,5\%, Perubahan Tarif tidak berpengaruh terhadap Kepatuhan Wajib Pajak dibuktikan dengan nilai siginifakan sebesar 28,8\%, dan Kesadaran Perpajakan (M) bukan merupakan variabel yang memperkuat atau memperlemah hubungan variabel Persepsi Keadilan Pajak, Pemahaman Perpajakan, dan Perubahan Tarif Pajak terhadap Kepatuhan Wajib Pajak dengan probabilitas signifikan sebesar $12,7 \%$.

Kata kunci: Persepsi Keadilan, Pemahaman Perpajakan, Perubahan Tarif, Kesadaran Perpajakan, Kepatuhan Wajib Pajak.

\section{PENDAHULUAN}

Pajak merupakan salah satu bentuk iuran wajib pajak yang wajib diberikan kepada negara yang terutang oleh orang pribadi maupun badan yang sifatnya memaksa tanpa mendapat imbal jasa secara langsung. Kontribusi yang diberikan kepada negara akan digunakan untuk membangun kemakmuran rakyat. Pajak berfungsi sebagai penggerak kegiatan negara, jadi perputaran keuanga negara akan akan sulit tanpa pemasukan pajak.

Sampai saat ini masyarakat masih takut untuk membayar pajak, karena mereka beranggapan kalau uang pajak yang dibayarkan kepada negara digunakan untuk kepentingan negara. Persepsi masyarakat seperti ini dapat disebabkan oleh beberapa faktor yang belum sepenuhnya dipahami, baik dari segi peraturan, jenis pajak, manfaat pajak, bagaimana cara menghitung, menyetor, dan melaporkan pajak. Apabila masyarakat memahami peraturan perpajakan kemungkinan kecil wajib pajak tidak akan melanggar dan akan menjalankan kewajiban perpajakanya (Sormin, 2018: 1).

Kepatuhan perpajakan merupakan ketaaatan wajib pajak untuk melaksanakan ketentuan perpajakan yang berlaku sesuai dengan undangundang. Wajib pajak dikatakan patuh adalah wajib pajak yang menaati dan memenuhi kewajiban perpajakan sesuai dengan ketentuan peraturan perundang-undangan.

Untuk meningkatkan kepatuhan wajib pajak, Direktorat Jendral Pajak selalu mengoptimalkan kemud ahan dalam melaksanakan kewajiban untuk membayar pajak, sehingga dapat meningkatkan kesadaran dan kemauan agar dapat berperan aktif dalam berkontribusi kepada negara. Salah satu usaha Diretorat Jendral Pajak untuk meningkatkan kepatuhan wajib pajak yaitu dengan menyederhanakan tarif PPh Final. 
Siti Dewi Yuliani dan Nina Dwi Setyaningsih: Faktor-Faktor yang Mempengaruhi Kepatuhan Wajib Pajak dengan Kesadaran Perpajakan sebagai Variabel Moderating

Dikeluarkannya PP No 23 Tahun 2018 dengan tarif 0,5\%, pengenaan tarif yang lebih rendah dan juga proses yang lebih mudah diharapkan mampu mendorong pelaku pengusaha UMKM baik yang sudah mempunyai NPWP maupun belum memliki untuk bisa melaksanakan kewajibannya. Selain itu, tujuan menyederhanaan tarif $0,5 \%$ adalah untuk meringankan pelaku wajib pajak serta menyetarakan sistem keadilan bagi seluruh pelaku pengusaha UMKM. Berdasarkan uraian diatas, ada berapa faktor yang mempengaruhi kepatuhan wajib pajak.Penelitian Andayani, dkk (2018) menyatakan bahwa persepsi keadilan berpengaruh terhadap kepatuhan wajib pajak. Faktor kedua yaitu pemahaman peraturan perpajakan. Menurut Jayanti (2017) pemahaman perpajakan tidak berpengaruh disgnifikan terhadap kepatuhan wajib pajak. Apabila pelaku wajib pajak memiliki pengetahuan atas pemahaman peraturan perpajakan maka secara otomatif kesadaran wajib pajak tinggi dan akan semakin patuh untuk mambayar iuran untuk negara atau pajak secara rutin dan tepat waktu. Tidak semua pelaku UMKM patuh terhadap pajak, kepatuhan wajib pajak untuk membayar pajak belum menunjukkan akan angka yag tinggi. Faktor selanjutnya yang menjadi pertimbangan atas terbitnya PP No.23 Tahun 2018 adalah perubahan tarif pajak. Dalam penelitian Ramdan (2017) menyimpulkan perubahan tarif pada PP No 46 Tahun 2013 berpengaruh terhadap kepatuhan wajib pajak.

Pada penelitian ini, peneliti menggunakan persepsi keadilan, pemahaman perpajakan, dan perubahan tarif sebagai variabel independen, dan kepatuhan wajib pajak UMKM sebagai variabel dependen.Berbeda dengan penelitian sebelumnya, peneliti menambah satu variabel yaitu kesadaran perpajakan sebagai variabel moderating, yang tujuannya adalah untuk mengetahui apakah persepsi keadilan, pemahaman perpajakan, dan perubahan tarif dapat ditingkatkan dengan adanya kesadaran perpajakan untuk meningkatkan kepatuhan wajib pajak UMKM setellah penerapan PP No. 23 Tahun 2018. Beradasarkan uraian diatas, maka penulis tertarik untuk melakukan penelitian dengan judul "Pengaruh Faktor-Faktor Yang Mempengaruhi Kepatuhan Wajib Pajak Dengan Kesadaran Perpajakan Sebagai Variabel Moderating".

Rumusan masalah pada penelitian ini adalah bagaiamana pengaruh persepsi keadilan, pemhaman perpajkaan, perubahan tarif terhadap kepatuhan 
Siti Dewi Yuliani dan Nina Dwi Setyaningsih: Faktor-Faktor yang Mempengaruhi Kepatuhan Wajib Pajak dengan Kesadaran Perpajakan sebagai Variabel Moderating

wajib pajak UMKM dengan kesadara perpajkan sebagai variabel moderating.dari rumusan masalah yang di buat dapat diambil tujuan dari penelitian ini apakah variabel persepsi keadilan, pemahaman perpajakan, perubahan tarif terhadap kepatuhan wajib pajak UMKM dan apakah dengan adaya variabel moderating kesaaran perpajakan dapat memperkuat atau memperlemah variabel persepsi keadilan, pemahaman perpajakan, dan perubahan tarif terhadap kepatuhan wajib pajak.

\section{KAJIAN PUSTAKA}

\section{Usaha Mikro, Kecil, dan Menengah (UMKM)}

UMKM saat menjadi pusat perhatian negara karena UMKM menjadi tulang punggung perekonomian. Peranan UMKM sangat penting di setiap negara, karena jumlah UMKM merupakan jumlah terbesar dari kegitan usaha disuatu negara. Usaha mikro kecil menengah (UMKM) terus mengalami peningkatan di Indonesia. Tingkat perumbuhan tidak hanya terjadi di kota-kota besar saja, namun sekarang hampir seluruh kota dan pelosok. Selain itu, UMKM juga menjadi salah satu pelaku usaha penting dari sekian banyak kegiatan ekonomi di Indonesia, oleh karena itu UMKM mendapat perhatian khusus dari pemerintah untuk pemberdayaan dan pengembangan. Hal ini dapat dilihat dengan adanya regulasi khusus mengenai UMKM yaitu dengan UU No 20 Tahun 2008 tentang Usaha Mikro Kecil Menengah (UMKM) (Pandiangan, 2014: $11)$.

\section{Pajak}

Pajak yaitu iuran masyarakat atau wajib pajak yang merupakan hak pemerintah, pemungutan pajak dilakukan berdasarkan undang-undang yang memiliki sifat memaksa yang diajukan kepada waji pajak dan dimana waji pajak tidak dapat merasakan balas jasa secara langsung dari pemerintah akan tetapi langsung dapat ditunjukkan penggunaanya (Mardiasmo, 2011: 1).

\section{Fungsi Pajak}

Pengertian Fungsi pajak adalah sebagai salah satu alat untuk menetukan politik perekonomian suatu negara, pajak memiliki fungsi pokok dalam meningkatkan kesejahteraan umum. Maka dengan alat politik perekonomian ini dapat menjadikan tulang punggung untuk meningkatkan kesejahteraan 
Siti Dewi Yuliani dan Nina Dwi Setyaningsih: Faktor-Faktor yang Mempengaruhi Kepatuhan Wajib Pajak dengan Kesadaran Perpajakan sebagai Variabel Moderating

masyarakat baik dalam bidang ekonomi, sosial, hukum, dan ketahaan negara. Secara umum fungsi pajak dikenal empat macam yaitu (Rahayu, 2017: 33): Fungsi Budgetair, fungsi regulerend, fungsistabilitas, fungsi retrisdibusi pendapatan.

\section{Pajak Penghasilan}

Pajak penghasilan (PPh) merupakan pajak yang mengatur pengenaan pajak penghasilan yang diperoleh dalam masa satu tahun pajak. Subjek pajak penghasilan akan dikenai pajak apabila memperoleh penghasilan, dalam Undang-Undang PPh disebut wajib pajak, wajib pajak dikenai pajak atas penghasiilan yang diperoleh selama satu tahun masa pajak dan dapat juga dikenai pajak untuk penghasilan dalam tahun pajak apabila pajak subjektifnya dimulai atau berakhir dalam masa tahun pajak (Mardiasmo, 2011: 135).

\section{Pemahaman Pemerintah No. 23 Tahun 2018}

Sebelumnya pada tahun 2013 yang lalu telah dikeluarkan PP No. 46/ 2013 yang mengatur bahwa WPOP yang melakukan kegiatan usaha atau pekerjaan bebas dan wajib pajak badan yang peredaran brutonya tidak melebihi $\mathrm{Rp}$ 4.800.000.000.000 dalam satu tahun pajak,mneghitung pajaknya secara final dengan tarif 1\% dari peredaran usaha setiap bulan (Anjarwati, 2009: 70). Dengan beberapa pertimbangan oleh pemerintah dan Ditjen Jendral maka Pajak PP No. 46 Tahun 2013 direvisi dan diganti PP No. 23 Tahun 2018 dan ditetapkan pada bulan Juli 2018 kemarin. Peraturan Pemerintah Republik Indonesia Nomor 23 Tahun 2018 tentang pajak penghasilan atas penghasilan dari usaha yang diterima atau diperoleh wajib pajak yang memiliki peredaran bruto tertentu.

\section{Persepsi Keadilan Pajak}

Dalam kegiatan pemungutan pajak harus bersifat adil dan merata, artinya pajak dikenakan pada orang pribadi yang harus sebanding dengan kemampuan membayar pajak atau ability to pay dan sesuai dengan manfaat yang diterima. Keadilan pemungutan pajak merupakan asas yang harus mendasari hukum pemungutan pajak yang dilakukan negara. Pemungutan pajak dikatakan adil karena pada dasarnya pemungutan pajak yang dilakukan oleh negara kembali lagi kepada warga negara dengan segala konsekuensi dan aturannya. Akan tetapi terkadang masyarakat menganggap pajak tidak sesuai dengan maksud keadilan yang menjadi asasdari perpajakan ( Rahayu, 2017: 63). 
Siti Dewi Yuliani dan Nina Dwi Setyaningsih: Faktor-Faktor yang Mempengaruhi Kepatuhan Wajib Pajak dengan Kesadaran Perpajakan sebagai Variabel Moderating

\section{Pemahaman Perpajakan PP No 23 Tahun 2018}

Pemahaman wajib pajak atas Peraturan Pemerintah PP No. 23 Tahun 2018 merupakan tingkat kemampuan dan pengetahuan wajib pajak atas diberlakunya PP No. 23 Tahun 2018, baik secara konten maupun secara administrasinya. Dengan pamahaman wajib pajak maka pengetahuan wajin pajak terkait dengan PP yang berlaku memberikan gambaran secara rasional bagi wajib pajak dalam mengartikan isi PP No. 23 Tahun 2018 dan dapat mendorong wajib pajak secara teknis dalam memenuhi kewajibannya baik dalam pelaksanaan administrasi, perhitungan, pembayaran dan pelaporannya.

\section{Perubahan Tarif Pajak}

Pemungutan pajak tidak dapat dilepas dari keadilan,hanya keadilan yang dapat menciptakan keseimbangan sosial yang sangat penting untuk kesejahteraan masayarakat umum. (Rahayu, 2017: 186). Oleh karena itu, agar persepsi masyarakat atau pelaku wajib pajak agar tidak menghindar akan membayar iuran kepada negara, maka pemerintah melakukan penurunan tarif yang tertuang pada PP No. 23 Tahun 2018 yaitu penurunan tarif sebesar 0,5\%. Penurunan tarif pajak agar masyarakat atau pelaku wajib pajak tidak terbebani lagi. Dengan penuruan tarif pada pelaku UMKM, akan membantu pelaku usaha bisa lebih menyimpan sebagian penghasilannya dan sebagian lagi untuk iuran yang dimasukkan ke kas negara.

\section{Kesadaran Perpajakan}

Kesadaran pajak merupakan keadaan atau sikap dimana wajib pajak mengerti, memahami, mengakui, mengakui dan menghargai dan menaati ketentuan perpajakan yang berlaku serta emmepunyai rasa kesungguhan dan rasa keinginann untuk mmenuhi kewajiban perpajakan seseui dengan undangundang. Kesadaran pajak selain untuk kepatuhan pajak juga menimbulkan sikap kritis dalam menyikapi perpajakan, sperti kebijkaan-kebijakan pajak yang ditetapkan pemerintah.

\section{Kepatuhan Wajib Pajak}

Kepatuhan perpajakan merupakan dimana wajib pajak taat dalam melaksanakan ketentuan perpajakan yang berlaku. Wajib pajak yang patuh adalah wajib pajak yang taat memenuhi kewajibannya sesuai dengan perundang-undangan (Rahayu, 2017: 192). 
Siti Dewi Yuliani dan Nina Dwi Setyaningsih: Faktor-Faktor yang Mempengaruhi Kepatuhan Wajib Pajak dengan Kesadaran Perpajakan sebagai Variabel Moderating

\section{Pajak dalam Perspektif Islam}

Pajak dalam ajaran islam seperti halnya seseorang yang dikatakan sudah mampu dan wajib untuk mengeluarkan zakat. Zakat merupakan mengeluarkan sebagian harta yang dimiliki untuk diberikan kepada orang yang berhak menerimnya (mustahik zakat). Zakat tidak hanya untuk menciptakan pertumbuhan ekonomi bagi orang-orang miskin, tetapi juga dapat mengembangkan jiwa dan kekayaan orang-orang kaya (Hardhawi, 2001: 34).

\section{HIPOTESIS}

Pada penelitian Sari (2014) bahwa variabel persepsi keadilan tidak berpengaruh terhadap kepatuhan wajib pajak UMKM yang dikenakan pada pajak penghasilan PP No 46 Tahun 2013. Berbeda dengan penelitian yang dilakukan oleh Wulandari dan Budiaji (2017) menyimpulkan persepsi keadilan berpengaruh terhadap kepatuhan wajib pajak UMKM dan didukung oleh penelitian Tiong (2014) persepsi keadilan berpegaruh terhadap kepatuhan wajib pajak UMKM. Dari penjelasan diatas maka hipotesis yang pertaman dalam penelitian ini adalah

H1 : Persepsi keadilan berpengaruh positif terhadap kepatuhan wajib pajak UMKM setelah penerapan PP No 23 Tahun 2018.

Dalam penelitian penelitian yang dilakukan oleh Jayanti (2017) menyimpulkan pemahaman perpajakan tidak berpengaruh signifikan terhadap tingkat kepatuhan wajib pajak. Tingkat pemahaman perpajakan diliat dari seberapa besar wajib pajak memahami peraturan perpajakan yang berlaku. Berbeda dengan penelitian yang dilakukan Primandani dan Haryono (2017) menjelaskan pemahaman perpajakan berpengaruh positif terhadap PPNo 46 Tahun 2013, dan penelitian Andriyani dan Wahid (2017) pemahaman perpajakan atas PP No 46 Tahun 2013 berpengaruh positif dan signifikan terhadap kepatuhan wajib pajak pelaku sentra industry kecil dan menengah. Dari penjelasan diatas maka hipotesis yang pertama dalam penelitian ini adalah:

H2: Pemahaman Perpajakan berpengaruh positif terhadap kepatuhan wajib pajak UMKM setelah penerapan PP No 23 Tahun 2018.

Ramdan (2017) dalam penelitiannya menjelaskan perubahan tarif berpengaruh positif terhadap kepatuhan wajib pajak UMKM didukung oleh 
Siti Dewi Yuliani dan Nina Dwi Setyaningsih: Faktor-Faktor yang Mempengaruhi Kepatuhan Wajib Pajak dengan Kesadaran Perpajakan sebagai Variabel Moderating

penelitan yang dilakukan Noza (2016) menyimpulkan perubahan tarif berpengaruh terhadap tingkat kepatuhan wajib pajak UMKM. Dari penjelasan diatas maka hipotesis yang pertaman dalam penelitian ini adalah:

H3 : Kesadaran perpajakan memoderasi perubahan tarif terhadap kepatuhan wajib pajak UMKM setelah penerapan PP No 23 Tahun 2018.

Menurut Macrori (2018) tingkat kepatuhan wajib pajak dapat tercapai apabila semakin tinggi tingkat kesadaran wajib pajak untuk membayar pajak maka akan semakin tinggi pula tingkat kepatuhan wajib pajak dalam membayar pajak. Dari penjelasan diatas maka hipotesis yang dapat ditarik adalah:

H4 : Kesadaran perpajakan memoderasi pemahaman perpajakan terhadap kepatuhan wajib pajak UMKM setelah penerapan PP No 23 Tahun 2018.

\section{METODE}

Penelitian Pengaruh Persepsi Keadilan, Pemahaman Perpajakan, Dan Perubahan Tarif Terhadap Kepatuhan Wajib Pajak Dengan Kesadaran Perpajakan Sebagai Variabel Moderating Pada Pelaku Umkm Setelah Penerapan PP No 23 Tahun 2018 menggunakan metode kuantitatif dengan pendekatan deskriptif (Sugiyono, 2015: 13). Metode pengumpulan data dalam penelitian ini menggunakan metode survei. Penelitian ini dilakukan pada UMKM yang terdaftar di KPP Pratama Bojonegoro.

\section{Populasi dan Sampel}

Populasi yang diambil dalam penelitian ini adalah pengusaha UMKM yang terdaftar di KPP Pratama Bojonegoro. Jumlah keseluruhan populasi yang terdafdar di KPP Pratama Bojonegoro pada tahun 2018 sebanyak 31.520 wajib pajak. Sampel dalam penelitian ini berjumlah 100 wajib pajak yang terdaftar di KPP Pratama Bojonegoro.

\section{Teknik Pengambilan Sampel}

Penentuan jumlah sampel untuk penelitian ini adalah menggunakan teknik Simple Random Sampling.Simple Random Sampling adalah pengambilan anggota sample dari populasi yang dilakukan secara acak (Sugiyono, 2013:122). 
Siti Dewi Yuliani dan Nina Dwi Setyaningsih: Faktor-Faktor yang Mempengaruhi Kepatuhan Wajib Pajak dengan Kesadaran Perpajakan sebagai Variabel Moderating

\section{Data dan Jenis Data}

Dalam penelitian ini data primer yang digunakan adalah kuesioner yang jawaban dari pernyataan diperoleh langsung dari responden. Data sekunder yang digunakan oleh peneliti adalah data UMKM yang terdaftar di KPP Pratama Bojonegoro.

\section{Teknik Pengumpulan Data}

Kuesioner merupakan teknik pengumpulan data yang dilakukan dengan cara memberi seperangkat pertanyaan atau pernyataan tertulis kepada responden untuk dijawab (Sugiyono, 2009: 199). Kuesioner dalam penelitian ini adalah menyebar angket kepada seluruh responden yang terdaftar di KPP Pratama Bojonegoro.

\section{Pengujian Hipotesis}

\section{Pengujian secara Persial (Uji T)}

Uji T digunakan untuk melakukan pengujian secara persial atau tidaknya hubungan antara variabel-variabel independen yaitu Persepsi Keadilan (X1), Pemahaman perpajakan (X2), Perubahan Tarif Pajak (X3) dengan variabel dependen Kepatuhan Wajib Pajak (Y). Untuk mengetahui apakah variabel bebas signifikan atau tidak terhadap variabel terikat secara individual pada taraf kesalahan yang dipilih yakni taraf 5\% (a=0,05). Cara lain dengan membandingkan $t_{\text {hitung }}$ dengan $t_{\text {tabel. }}$. Jika $t_{\text {hitung }}>t_{\text {tabel }}$ maka dapat disimpulkan bahwa secara persial variabel independen berpengaruh signifikan terhadap variabel dependen (Latan dan Temalagi, 2013: 81).

\section{Pengujian Secara Simultan (Uji F)}

Uji $\mathrm{F}$ atau uji koefisien serentak dilakukan untuk mngetahui pengaruh variabel independen secara serentak terhadap variabel independen, apakah pengaruh signifikan atau tidak signifikan adalah jika $\mathrm{p}$ value $<0,05$ atau menggunakan F hitung dan F kritis. Cara menguji yaitu jika nilai yang dihasilkan uji $F$ probabilitas <0,05 maka dapat disimpulkan baaahwa semua variabel independen secara simultan berpengaruh signifikan terhadap variabel dependen. Cara lain membandingkan $\mathrm{F}_{\text {hitung }}$ dengan $\mathrm{F}_{\text {tabel. Jika }} \mathrm{F}_{\text {hitung }}>\mathrm{F}_{\text {tabel, }}$ maka dapat disimpulkan semua variabel independen secara simultan berpengaruh signifikan terhadap variabel dependen (Latan dan Temalagi, 2013: 81). 
Siti Dewi Yuliani dan Nina Dwi Setyaningsih: Faktor-Faktor yang Mempengaruhi Kepatuhan Wajib Pajak dengan Kesadaran Perpajakan sebagai Variabel Moderating

\section{Analisis Koefisien Determinasi $\left(\mathbf{R}^{2}\right)$}

Koefisisen Determinasi $\left(R^{2}\right)$ bertujuan untuk menunjukkan seberapa nbesar kemampuan variabel independen dalam menjelaskan variasi variabel dependen. Nilai koefisien determinasi antara 0 dan 1 . Nilai koefisien determinasi menunjukkan nilai kecil artinya kemampuan variabel independen dalam menjelaskan variabel dependen amat terbatas. Pengujian tes regresi akan dianalis dengan menggunakan progam komputer pengolahan data statistik SPSS.

\section{HASIL DAN PEMBAHASAN}

\section{Uji Asumsi Klasik}

\section{Uji Normalitas}

Dari hasil pengujian, diperoleh Kolmogrov-Smirnov Z senilai 0,559 dengan nilai signifikan Asmp. Sig. (2-tailed) 0,914. Karena nilai signifikan lebih besar dari 5\%, maka nilai residual tersebut adalah normal. Faktor lain yang dapat digunakan untuk mrmbuktikan apakah data terdistribusi dengan normal yaitu dengan melihat histogram dan grafik normal.

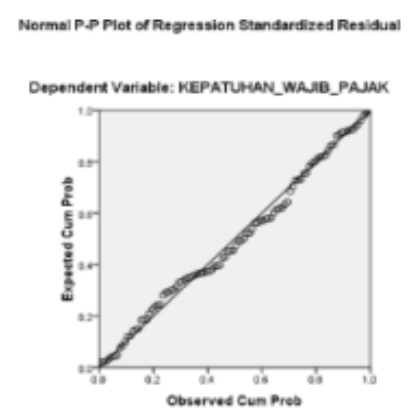

Menunjukkan bahwa data berdistribusi normal karena bentuk grafik normal dan tidak melenceng ke kanan ataupun ke kiri. Gambar 4.2 dari grafik normal plot dapat dilihat titik-titik yang tersebar disekitar garis diagonal dan penyebaran titik-titik mengikuti garis diagonal. Hal ini menunjukkan bahwa model regresi dalam penelitian memenuhi uji asumsi normalitas.

\section{Uji Multikolonieritas}

Berdasarkan hasil data, dapat dketahui hasil pengujian pada tabel 4.9, bahwa nilai tolerance semua variabel persepsi keadilan, pemahaman perpajakan, 
Siti Dewi Yuliani dan Nina Dwi Setyaningsih: Faktor-Faktor yang Mempengaruhi Kepatuhan Wajib Pajak dengan Kesadaran Perpajakan sebagai Variabel Moderating

perubahan tarif pajak, dan kesadaran perpajakan lebih besar dari 0,10, maka dapat disimpulkan bahwa tidak terjadi multikolonieritas.

\section{Uji Heterorkedastisitas}

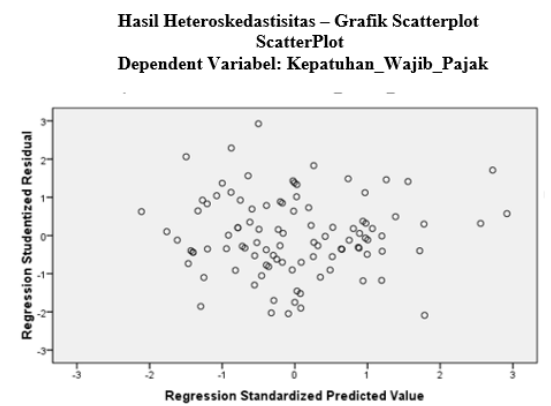

Hasil uji heteroskedastisits dapat dilihat dari gambar 4.5 bahwa grafik scatterplot antara SRESID dan ZPRED menunjukkan pola penyebaran, dimana titik-titik menyebar secara acak dan tersebar merata ke atas dan ke bawah angka 0 pada sumbu Y. Sehingga dapat disimpulkan bahwa tidak terjadi heteroskedastisitas pada model regresi, an regresi layak dipakai untuk memprediksi kepatuhan wajib pajak berdasarkan persepsi keadilan pajak, pemahaman perajakan, perubahan tarif pajak, dan keasadaran perpajakan.

\section{Hasil Uji Hipotesis Regresi Linier Berganda ( H1, H2, H3)}

a. Persepsi keadilan pajak berpengaruh positif dan signifikan terhadap kepatuhan wajib pajak UMKM (H1)

Persepsi keadilan pajak memilik $\mathrm{t}$ hitung sebesar 4,092 > sementara $\mathrm{t}$ tabel dengan signifikan $\alpha=0,05$ dan $d f=n-k$, yaitu $100-4=96, \mathrm{t}$ tabel 1,985 dengan tingkat signifikan 0,000 yang lebih kecil dari 0,05, maka Ha diterima. Dari hasil analisis ini berarti persepsi keadilan pajak berpengaruh positif terhadap kepatuhan wajib pajak UMKM terbukti.

b. Pemahaman perpajakan berpengaruh positif dan signifikan terhadap kepatuhan wajib pajak UMKM (H2)

Variabel pemahaman perpajakan memilliki $t$ hitung sebesar 6,729 > t tabel 1,985 dengan tingkat signifikan 0,000 yang lebih kecil dari 0,05, maka Ha diterima. Dari hasil analisis ini berarti pemahaman perpajakan berpengaruh positif terhadap kepatuhan wajib pajak UMKM terbukti.

c. Perubahan tarif pajak berpengaruh positif dan signifikan terhadap kepatuhan wajib pajak UMKM (H3) 
Siti Dewi Yuliani dan Nina Dwi Setyaningsih: Faktor-Faktor yang Mempengaruhi Kepatuhan Wajib Pajak dengan Kesadaran Perpajakan sebagai Variabel Moderating

Variabel perubahan tarif pajak memilliki $t$ hitung sebesar 1,300 > t tabel 1,985 dengan tingkat signifikan 1,97 yang lebih besar dari 0,05, maka Ha ditolak. Dari hasil analisis ini berarti perubahan tarif pajak tidak berpengaruh positif terhadap kepatuhan wajib pajak UMKM terbukti.

Hasil Uji Regresi Moderasi Dengan Pendekatan Nilai Selisih Muntlak (H4, H5, H6)

Dari hasil uji nilai selisih muntlak yang terlihat pada tabel 4.16 menunjukkan bahwa ABSX1_X2_X3_ZM ternyata tidak signifikan yaitu dengan probabilitas signifikan 0,127 dan jauh lebih tinggi dari 0,05. Maka Ha ditolak. Dapat disimpulkan bahwa kesadaran perpajakan bukan merupakan variabel yang memperkuat atau memperlemah hubungan variabel persepsi keadilan pajak, pemahaman perpajakan, dan perubahan tarif pajak terhadap kepatuhan wajib pajak. Jadi hipotesis H4, H5, H6 ditolak atau tidak terbukti.

\section{Pengaruh Persepsi Keadilan Pajak terhadap Kepatuhan Wajib Pajak UMKM}

Hipotesis pertama yang diajukan dalam penelitan ini adalah persepsi keadilan pajak dengan koefisien beta unstandardizet variabel persepsi keadilan pajak sebesar 0,432 dan nilai signifikan $t$ sebesar 0,000. Wajib pajak UMKM akan patuh apabila merasa sistem pemungutan pajak yang dilakukan telah sesuai dengan asas keadilan. Pemungutan pajak dikatakan adil karena pada dasarnya pemungutan pajak yang dilakukan oleh negara kembali lagi kepada warga negara dengan segala konsekuensi dan aturannya ( Rahayu, 2017: 63). Penelitian ini mendukung hasil penelitian Wulandari dan Budiaji (2017) menyimpulkan persepsi keadilan berpengaruh terhadap kepatuhan wajib pajak UMKM dan didukung oleh penelitian Tiong (2014) persepsi keadilan berpegaruh terhadap kepatuhan wajib pajak UMKM, dan menolak hasil penelitian Penelitian ini mendukung penelitian yang dilakukan oleh penelitian Sari (2014) bahwa variabel persepsi keadilan tidak berpengaruh terhadap kepatuhan wajib pajak UMKM.

\section{Pengaruh Pemahaman Perpajakan terhadap Kepatuhan Wajib Pajak UMKM}

Hipotesis kedua yang diajukan dalam penelitian ini adalah variabel pemahaman perpajakan dengan koefisien beta unstandardizet sebesar 6,729 dan nilai signifikan sebesar 0,000. Berdasarkan hasil dari analisis pemahaman perpajakan berpengaruh postitif terhadap kepatuhan wajib pajak UMKM. Seperti hasil 
Siti Dewi Yuliani dan Nina Dwi Setyaningsih: Faktor-Faktor yang Mempengaruhi Kepatuhan Wajib Pajak dengan Kesadaran Perpajakan sebagai Variabel Moderating

penelitian yang dilakukan oleh Primandani dan Haryono (2017) menjelaskan pemahaman perpajakan berpengaruh positif terhadap PP No 46 Tahun 2013, dan penelitian Andriyani dan Wahid (2017) pemahaman perpajakan atas PP No 46 Tahun 2013 berpengaruh positif dan signifikan terhadap kepatuhan wajib pajak pelaku sentra industry kecil dan menengah.Akan tetapi hasil penelitian ini menolak hasil uji yang dilaukan oleh Jayanti (2017) menyimpulkan pemahaman perpajakan tidak berpengaruh signifikan terhadap tingkat kepatuhan wajib pajak.Pemahaman wajib pajak logis apabila dihubungan dengan tingkat kepatuhan wajib pajak. Karena hal ini sesuai dengan sistem perpajakan yang berlaku saat ini yaitu Self Assesment System. Apabila wajib pajak tidak memahami peraturan perpajakan maka akan sulit untuk melaksanakan kewajiban perpajakannya.

\section{Pengaruh Perubahan Tarif Pajak terhadap Kepatuhan Wajib Pajak UMKM}

Hipotesis ketiga yang diajukan dalam penelitian adalah perubahan tarif pajak dengan koefisien beta unstandardizet sebesar 1,300 dan nilai signifikan sebesar 0,197. Berdasarkan hasil dari analisis perubahan tarif pajak tidak berpengaruh terhadap kepatuhan wajib pajak UMKM.Penelitian ini menolak hasil penelitian yang dilakukan oleh Ramdan (2017) dalam penelitiannya menjelaskan perubahan tarif berpengaruh positif terhadap kepatuhan wajib pajak UMKM didukung oleh penelitan yang dilakukan Noza (2016) menyimpulkan perubahan tarif berpengaruh terhadap tingkat kepatuhan wajib pajak UMKM.Tarif pajak diartikan sebagai persentase yang disetorkan oleh wajib pajak sesuai dengan penghasilan dan undang-undang yang berlaku. Penyederhanaan tarif pajak 0,5\% ada yang menganggap bahwa tarif pajak tersebut masih tinggi dan masih sama dengan tarif sebelumnya.

\section{Kesadaran Perpajakan dalam Memoderasi Persepsi Keadilan Pajak, Pemahaman Perpajakan dan Perubahan Tarif Pajak Terhadap Kepatuhan Wajib Pajak UMKM}

Hipotesis ke empat, lima, dan enam yang diajukan dalam penelitian ini adalah kesadaran perpajakan memoderasi persepsi keadilan pajak, kesadaran perpajakan memoderasi pemahaman perpajakan, kesadaran perpajakan memoderasi perubahan tarif pajak dengan koefisien beta unstandardizet sebesar 0,361 dengan nilai signifikan 0,127. Berdasarkan analisis bahwa interaksi persepsi 
Siti Dewi Yuliani dan Nina Dwi Setyaningsih: Faktor-Faktor yang Mempengaruhi Kepatuhan Wajib Pajak dengan Kesadaran Perpajakan sebagai Variabel Moderating

keadilan pajak, pemahaman perpajakan, perubahan tarif pajak dan kesadaran perpajakan tidak berpengaruh terhadap kepatuhan wajib pajak UMKM. Hal in berarti semua hipotesis yang menyatakan kesadaran perpajakan memoderasi persepsi keadilan, pemahaman perpajakan, perubahan tarif pajak terhadap kepatuhan wajib pajak ditolak.

\section{KESIMPULAN DAN SARAN}

\section{Kesimpulan}

1. Berdasarkan analisis yang sudah dilakukan menunjukan bahwa persepsi keadilan pajak berpengaruh positif terhadap kepatuhan wajib pajak UMKM dengan nilai signfikan sebesar 43,2\%. Hal ini berarti semakin baik persepsi keadilan maka kepatuhan wajib pajak akan semakin baik.

2. Berdasarkan analisis yang sudah dilakukan menunjukan bahwa pemahaman perpajakan berpengaruh positif terhadap kepatuhan wajib pajak UMKM dengan nilai signfikan sebesar $74,5 \%$. Hal ini berarti semakin baik pemahaman perpajakan maka kepatuhan wajib pajak akan semakin baik.

3. Berdasarkan analisis yang sudah dilakukan menunjukan bahwa perubahan tarif pajak tidak berpengaruh terhadap kepatuhan wajib pajak UMKM dengan nilai signfikan sebesar 22,8\%. Hal ini berarti perubahan tarif pajak masih kurang baik sehingga tingkat kepatuhan wajib pajak tidak baik pula.

4. Hasil analisis regresi dengan pendekatan nilai selisih mutlak menunjukan bahwa interaksi keasadaran perpajakan dan persepsi keadilan pajak, pemahaman perpajakan, perubahan tarif pajak tidak berpengaruh terhadap kepatuhan wajib pajak UMKM hal ini berarti kesadaran perpajakan tidak merupakan variabel yang memoderasi persepsi keadilan pajak, pemahaman perpajakan, perubahan tarif pajak dengan nilai signfikan sebesar $12,7 \%$.

\section{Saran}

1. Bagi pihak pemerintah harus lebih bisa mengoptimalkan sosialisasi perpajakan tentang pengetahuan dan pemahaman perpajakan bagi wajib pajak UMKM khusunya tata cara mendaftar dan cara mendapatkan 
Siti Dewi Yuliani dan Nina Dwi Setyaningsih: Faktor-Faktor yang Mempengaruhi Kepatuhan Wajib Pajak dengan Kesadaran Perpajakan sebagai Variabel Moderating

NPWP, cara menghitung dan menyetor, membayar dan melaporkan SPT, ketentuan dan peraturaan perpajakan yang terbaru kepada pelaku pengusaha UMKM.

2. Bagi peneliti selanjutnya disarankan menambah atau memperluas obyek penelitian dan menambah variabel yang lain yang lebih berpengaruh terhadap kepatuhan wajib pajak UMKM misalnya variabel sanksi pajak, manfaat membayar pajak, dan niat patuh membayar pajak.

\section{DAFTAR PUSTAKA}

Al-Qur'an Al-Kharim dan terjemahannya.

Andayani, Endro. 2018. "Pengaruh Faktor-Faktor Pelaksanaan PP 46 Tahun 2013 Terhadap Kepatuhan Wajib Pajak UMKM (study kasus UMKM Pusat Tanah Abang Jakarta Pusat)". Jurnal Transparasi Vol 1, No. 1, Juni 2018, pp. 12-28.

Andriani, Neneng Rina, Wahid, Nisa Noor. 2017. "Pengaruh Pemahaman Wajib Pajak Atas Peraturan Pemerintah Nomor 46 Tahun 2013 Terhadap Kepatuhan Wajib Pajak (Studi Kasus Pada Pelaku Sentra Industri Kecil dan Menengah Kota Tasikmalaya)". Jurnal Akuntansi Vol 12, Nomor 2, Juli Desember 2017.

Jayanti, Eka Dwi. 2017. "Pengaruh Penerapan E-Filing, Pemahaman Perpajakan Dan Kesadarn Wajib Pajak Terhadap Kepatuhan Wajib Pajak". Jurnal Skripsi. Progam Study Akauntansi. Sekolah Tinggi Ilmu Ekonomi Perbanas.

Kurnia, Siti Rahayu. 2017. Perpajakan. Cetakan Pertama. Bandung: Rekayasa Sains.

Latan, H dan Temalag, S. 2013. Analisis Multivariate Teknik Dan Aplikasi Menggunakan Progam IBM SPSS 20,0. Bandung: Alfabeta.

Mardiasmo. 2009. Perpajakan. Edisi kesembilan. Yogyakarta: Penerbit Andi.

Macrori, Fitri. 2018. “Pengaruh Kesadaran Wjib Pajak, Pelayaan Fiskus, Dan Sanksi Pajak Terhadap Kepatuhan Wajib Pajak Orang Pribadi Yang Melakukan Usaha Kecil Menengah (Study Empiris Pada Kantor Pelayanan Penyuluhan Dan Konsultasi Perpajakan Kota Sungai Penuh). Jurnal Skripsi. Fakultas Ekonomi. Universitas Negeri Padang.

Noza, Claressa AA. 2016. “Pengaruh perubahan tarif, Kemudahan Membayar Pajak, Sanksi Pajak, Dan Sosialisasi PP No 46 Tahun 2013 Terhadap Tingkat Kepatuhan Wajib Pajak Pelaku UMKM". Jurnal Publikasi Ilmiah. Progam Study Akuntansi Fakultas Ekonomi Dan Bisnis. Universitas Muhammadiyah Surakarta 
Siti Dewi Yuliani dan Nina Dwi Setyaningsih: Faktor-Faktor yang Mempengaruhi Kepatuhan Wajib Pajak dengan Kesadaran Perpajakan sebagai Variabel Moderating

Pandiangan, Liberti. 2014. Mudahnya menghitung pajak UMKM. Edisi Pertama. Jakarta: Mitra Wacana Media.

Primandani.I, Syafi'i, Haryono. 2017. “Analisis Perilak u Kepatuhan, Pemahaman, Dan Kemudahan Wajib Pajak UMKM Terhadap Peraturan Pemerintah No 46 Tahun 2013pada KPP Pratama Mulyorejo". Jurnal Ekonomi Akuntansi. Vol. 3, Issue. 3 (2017). Universitas Bhayangkara Surabaya.

Ramdan, Andy Nurmansyah. 2017. "Pengaruh Perubahan Tarif, Metode Perhitungan Dan Man Modernisasi Sistem Pajak Terhadap Kepatuhan Wajib Pajak UMKM Dengan Keadilan Pajak Sebagai Variabel Moderating Pada UMKM Dikota Makassar". Jurnal Skripsi. Jurusan Akuntansi. Fakultas Dan Bisnis Islam UIN Alauddin Makassar.

Sugiyono, 2009. Metode Penelitian Kuantitatif Kualitatif dan RED. Bandung: CV Alfabeta.

2012. Metode Penelitian Kuantitatif Kualitatif dan RED. Cetakan ketujuh belas. Bandung: Alfabeta.

2015. Metode Penelitian Pendidikan Pendekatan Kuantitatif, Kualitatif, dan R\&D. Cetakan Kedua Puluh Dua. Bandung: Alfabeta.

Sari, Melisa Anita. 2014. "Pengaruh Persepsi Keadilan Pajak Dan Persepsi Kemudahan Perpajakan Terhadap Kepatuhan Wajib Pajak Kelompok UMKM Pasca Penetapan Peraturan Pemerintah Nomor 46 Tahun 2013". Jurnal Skripsi. http://www.academia.edu/11560670/ JURNAL_SKRIPSI_MELISA.

Tiong, Ka. 2014. “Pengaruh Pelaksanaan PP No 46 Tahun 2013 Terhadap Kepatuhan Wjib Pajak UMKM (study kasus UMKM ynag terdaftar di Wilayah DKI Mega Glodok Kemayoran). Progam Pasca SarjanaMagister Akuntansi. Universitas Mercu Buana.

Wulandari, Soliyah. 2017. “Pengaruh Persepsi Keadilan Pajak Dalam Peraturan Pemerintah Republik Indonesia Nomor 46 Tahun 2013 Terhadap Kepatuhan Dalam Memenuhi Kewajiban Perpajakan". Jurnal Ekonomi Islam, Vol. 8, No. 2 Juli-Desember 2017. P-ISSN: 2541-4127. Page: 239-268. 